\title{
The usage of behaviour based safety process for decreasing work-related musculoskeletal diseases at the sales department of a factory
}

\section{Mesleksel kas iskelet sistemi hastalıklarını azaltmada davranıș odaklı güvenlik sistemi uygulaması}

\author{
Ayşe COŞKUN-BEYAN ${ }^{1}$, Duygu TURŞUCU²
}

\section{ABSTRACT}

Objective: According to the International Labour Organisation, occupational diseases and work-related diseases are the musculoskeletal diseases in the first place. Ergonomic inadequacies such as monotonous tasks, repetitive movements, movements which require force, unhealthy body posture, unsafe acts and vibration have an important impact on the development of musculoskeletal diseases. In order to reduce ergonomics risks factors many interventions have been developing such as engineering, administrative, and behavioural/ personal interventions. The Behavioural Based Safety (BBS) process is a good example for behavioural / personal ergonomic interventions. Although BBS is used for occupational accident commonly, there is not many examples for occupational diseases.

Methods: The BBS system which was developed by factory health and safety professionals had been established in the factory 6 months ago. BBS was consisted four steps: I observed it, I solved it, I prevented it and I monitored it. Fifteen workers were trained and worked in this system actively. The system was implemented in 34 employees who work in the factory sales department. System was used as an example unsafe act that might caused occupational musculoskeletal diseases at factory sales department.

Results: Thirty-four employees were working at the

\section{ÖZET}

Amaç: Uluslararası Çalıșma Örgütüne göre meslek hastalıkları ve iș ile ilișkili hastalıkların ilk sıralarında mesleki kas iskelet sistemi hastalıkları (MKiSH) yer almaktadır. Bu hastalıkların oluşumunda monoton iș, iș yerinde tekrarlamalı ve zorlamalı hareketler, vücudun kötü pozisyonlarda kullanımı, hatalı davranıșlar ve titreșimi de içeren ergonomik yetersizlikler önemli rol oynar. Ergonomik risk faktörlerini azaltmak için işyerlerinde farklı yaklaşımlar -mühendislik, yönetsel ve davranışsal/kișisel - geliștirilmeye devam etmektedir. Davranıș odaklı güvenlik yaklașımı (DOGY) kişisel/davranışsal yaklaşımlara iyi bir örnektir. DOGY iş kazalarını önlemek için sıkça kullanılmaktadır. Meslek hastalıklarını önlemek için kullanım örneği azdir.

Yöntem: Fabrikada 6 ay önce fabrika iș sağlığı ve güvenliği profesyonelleri tarafından DOGY sistemi olușturulmuștur. DOGY gördüm, çözdüm, önledim ve izledim olmak üzere dört basamaktan olușmaktadır. 15 çalıșana eğitim verilerek bu sistemin içinde aktif görev verilmiştir. Sistem fabrika satıs bölümünde çalıșan 34 çalışana uygulanmıștır. Çalıșanların uzun dönemde mesleki kas iskelet sistemi hastalıklarına yol açabilecek bir davranış örneğinde sistem uygulanmıștır.

'Dokuz Eylul University Faculty Of Medicine, Occupational Disease Department, Izmir

${ }^{2}$ Factory Occupational Health And Safety Unit, Occupational Safety Department, Izmir

İletişim / Corresponding Author: Ayşe COŞKUN-BEYAN

Dokuz Eylül Üniversitesi Göğüs Hastalıkları Abd lzmir - Türkiye

Tel : +905069089711 E-posta/E-mail : dr.aysecoskun@hotmail.com

Geliş Tarihi / Received : 24.04.2016 Kabul Tarihi / Accepted : 11.08 .2017

DOI ID : 10.5505/TurkHijyen.2017.02170

Çoskun-Beyan A, Turșucu D. The usage of behaviour based safety process for decreasing work-related musculoskeletal diseases at the sales department of a factory. Turk Hij Den Biyol Derg, 2017; 74(4): 321-332 
sales department. Twenty-five $\mathbf{( 7 3 . 5 \% )}$ of the cases were male. The most common complaints were neck pain, which was expressed by $94.1 \%$ of the employees, and neck stiffness which was expressed by $44.1 \%$ of the employees. RULA score was $6.15 \pm 0.60$ prior the implementation, it was $5.12 \pm 0.80$ afterwards $(p<0.001)$. The presence of musculoskeletal complaints was $94.10 \%$ prior the implementation, while it was $61.7 \%$ afterwards $(p=0.03)$. The Sickness Absenteeism Incidence Rate (SAIR) prior the implementation was 235\%, while it was $176 \%$ o $(p<0.001)$ afterwards.

Conclusion: The BBS process is mainly used in researches which aim to prevent or decrease work-related accidents There are also a few examples, similar to our research, regarding its implementation at ergonomic interventions to prevent occupational diseases. As our research has been carried out only with a small group of employees it was able to successful by workers active role in all levels. This process may be considered as a promising approach for the prevention of OMDS. As to evluted the feasibility and the long terms results of the process it should be applied to larger groups. The system should be update according to the feed backs which are received after the implementation regularly.

Key Words: Ergonomics, behavioural based safety, occupational disease

\section{INTRODUCTION}

Occupational musculoskeletal system diseases (OMSD) represent the most common occupational and work-related health diseases all around the world (1). According to the World Health Organisation's data, OMSD account for $10 \%$ of all occupational workforce loss (2). Many ergonomic factors such as repetitive trauma, working in static postures for prolonged periods, heavy lifting, monotonous working conditions and personal factors have been described as risk factors that contribute to the development of these diseases
Bulgular: Fabrika satıș bölümünde 34 çalıșan vardı ve $25(\% 73,5)$ 'i erkekti. Çalışanların en sık yakınması boyun ağrısı $(\% 94,1)$ ve boyun tutulmasıydı $(\% 44,1)$. DOGY sistemi sonucu yapılan girișimler öncesi RULA skoru $6,15 \pm 0,60$ iken girișim sonrası $5,12 \pm 0,80$ idi $(p<0,001)$. Girișim öncesi kas iskelet sistemi yakınma sıklığı \%94,1 iken girișim sonrası \%61,7 olarak bulunmuștur $(p=0,03)$. Hastalık nedenli ișe gelememe hızı \%o235 iken hastalık sonrası \% 176 olarak bulunmuștur $(p<0,001)$.

Sonuç: DOGY daha çok iş kazalarını önlemek ya da azaltmak için kullanılmaktadır. Çalıșmamıza benzer șekilde meslek hastalıklarını önlemek için yapılacak girișimlerde az sayıda uygulama vardır. Az sayıda olguda uygulanmış olan uygulamamız meslek hastalıklarını önlemek için uygulanmıștır ve çalıșanların aktif olarak tüm basamaklarda rol oynaması nedeni ile bașarılı olmuștur. DOGY mesleki kas iskelet sistemi hastalıklarının önlenmesinde umut verici bir yaklașım gibi gözükmektedir. Uygulanabilirliğini ve uzun dönem sonuçlarını değerlendirebilmek için daha büyük gruplara uygulanmalıdır. Uygulama sonrası alınacak geri bildirimler ile sistem sürekli yenilenmelidir.

Anahtar Kelimeler: Ergonomi, davranıș odaklı güvenlik, meslek hastalıkları

(3). Various approaches have been developed in order to reduce the ergonomic risks in workplaces. Ergonomic interventions are commonly classified as engineering, administrative, and behavioural/ personal interventions. The Behavioural Based Safety (BBS) process is a good example for behavioural/ personal ergonomic interventions (4).

The BBS process can be described as an approach in which the employees observe their own colleagues' behaviours, and identify the unsafe acts that cause the most common work-related injuries 
and illnesses. Proactive approaches and interventions are based on these observations. BBS is a continuous four-step improvement process: Define, observe, intervene and finally test and monitor (5).

Heinrich (1931) is the 'father' of the current approach to safety programs. While he was founding the program, he used an extensive database from the insurance industry, and he concluded that most safety problems (almost 90\%) are the result of human error, which he called "unsafe acts". Heinrich based his intervention strategy on the development of safety rules to guide individual behaviour and thus avoid these unsafe acts (6).

Recently, many researchers have applied the BBS process in various settings such as construction sites, clinical medicine, manufacturing and mining industry (7-11). These successful examples demonstrate the effectiveness of a well-designed BBS process on modifying individuals' unsafe acts that are the cause of accident. These studies have revealed that the implementation of the BBS process leads to a significant decrease in work-related accidents (12, 13). On the other hand, only a few implementations have used the BBS process to prevent the occupational or work-related diseases (14).

In our research, we have presented the data obtained from the implementation of the BBS process that has been carried out in a factory by their workplace health and safety professionals (WHSP) in order to prevent work-related musculoskeletal diseases (WRMSD).

\section{MATERIAL and METHOD}

\section{The BBS process}

The BBS process had been established in the factory 6 months ago. The WHSP had selected 15 observing employees so that each section of the plant had been provided with at least one observer. The only criterion for being selected as an observer was to be working in that company for at least one year. The observers were trained according to the BBS training that was prepared by the WHSP.

Each week, the observers completed the notification forms that were prepared by the WHSP. The WHSP evaluated all the notifications at the end of each Friday and considered them according to their importance.

The notification forms consisted of four parts;

1) I have observed it: The unsafe act is described, and the time and place are specified. As the unsafe act may lead to work-related accidents or occupational diseases, the scenarios for how the potential accident or occupational disease may arise are assessed.

2) I have solved it: The observer offers solutions to prevent the potential occupational disease or work-related accident scenario.

3) I have prevented it: The observer and WHSP discuss the probable interventions that may be implemented in order to decrease or prevent the unsafe acts and chose the most suitable one together.

4) I have monitored it: The intervention that has been chosen is implemented and is monitored for a while.

\section{The data sources}

2.1. The information obtained from the factory's infirmary

The socio-demographic data of the employees, such as age, gender, marital status, smoking history, educational background and the number of sickness absence days, have been obtained from the infirmary records. Written authorization has been obtained from the physician responsible of the infirmary. 
The number of sickness absence days defines the number of days for which the employee has obtained a sickness absence report due to musculoskeletal system complaints that occurred in the last 3 months, either from the infirmary or from another health care provider.

\subsection{The questionnaire}

The questionnaire prepared by the WHSP has been applied. The existence and severity of the musculoskeletal system complaints have been evaluated twice; once before and once after the implementation.

3. The procedure for ergonomic risk assessment (ERA)

Rapid Upper Limb Assessment (RULA) scale has been used for ergonomic risk assessment. The incorrect posture while sitting in front of the computer and talking on the phone was defined as the unsafe act creating the risk, and the risk has been assessed according to the RULA user manual. Two separate WHSP have carried out the risk assessment. The final score has been obtained by the consensus of the two observers.

In 1992, Lynn Mc Atamney and E. Nigel Corlett have developed the RULA by using observational methods, in order to identify the upper extremity movements that may cause MSD (15). Esin et al have performed the validation and reliability assessment of the scale into Turkish (16).

The ERA has been performed twice, once before the implementation in order to assess the size of the risk and once after the implementation in order to assess its effectiveness.

\section{Correct standing and sitting posture} training

The WHSP have prepared a correct standing and sitting posture training, which has been given to 34 employees.

\section{Research population and sampling}

The research population consists of 34 employees working in the sales department of the factory. The sales department employees are responsible for calling customers in order to make sales, to evaluate customer complaints, and to respond incoming emails. Employees work inside a one square metre area divided by separators, and use a desktop computer and a telephone with a handset. All of the employees have been included in the research and sampling has not been performed.

6. The variables and statistical analysis

\subsection{The variables}

\subsubsection{Independent variables}

Gender, age, educational background, marital status, the presence of chronic diseases and smoking history have been identified as independent variables.

\subsubsection{Dependent variables}

6.1.2.1. RULA risk score: The RULA risk score has been defined according to the final score arising from the evaluation conducted by two separate observers.

\subsubsection{The number of sickness absence} days: The number of sickness absence days has been defined as the number of days for which the employee obtained a sickness absence report due to musculoskeletal system complaints either from the infirmary or from another health care provider.

\subsubsection{The presence of musculoskeletal} system complaints: The presence of neck pain, neck stiffness, and numbness and pins-and-needles sensation in arms has been classified as 'complaints 
present', and the lack of these complaints has been classified as 'complaints not present'.

\subsubsection{Sickness absenteeism incidence} rate (SAIR): The formula to calculate the sickness absenteeism incidence rate has been provided in the reference (17).

\section{Statistical analysis}

The research has been designed as an interventional study. The continuous variables have been presented with mean and standard deviation (for normal distribution data ) and median and minmax (for non-normal distribution data) statistics. In order to compare the values obtained prior and 3 months after the implementation, the Mc-Nemar chi-square test has been used for the categorical data, and the paired sample t-test and Wilcoxon test have been used for the digital data. The compliance with normal distribution has been evaluated with the Shapiro-Wilk test. The degree of statistical significance has been chosen as $\mathrm{p}=0.05$ at $95 \%$ confidence interval. SPSS 15.0 package programme has been used to perform all the statistical analyses.

\section{RESULTS}

1. The unsafe act selected by the observing employees and described according to the BBS

\subsection{The opinion of the employee:}

1) I have observed it: My colleagues working at the sales department continue to use their computer while speaking with their customers on phone, therefore their hands are occupied, and they hold the phone between their shoulder and head during the call. In addition to this, their sitting posture in front of the computer is incorrect. All these postural errors may lead to neck pain and cervical hernia.
2) I have solved it: The employees should be informed of the harms of using the phone this way. They may take calls with phones that have headphones. They should be given training for correct standing and sitting postures.

3) I have prevented it: The employees should be given training on ergonomics. A headphone system should be implemented.

4) I have monitored it: The efficacy of both the training and the usage of headphones should be assessed.

\subsection{The opinion of the WHSP}

The observations have been conducted on site, and the ERA score of the identified movement has been determined using the RULA scale.

The WHSP's comment regarding the BBS observers' opinion:

The suggestions made at the prevention step are appropriate. The sales representatives will be given training on ergonomics, a headphone system will be implemented, and the results will be assessed.

The employees' initial RULA risk score, the presence of musculoskeletal system complaints, the number of sickness absence days and the sickness absenteeism incidence rate have been compared with the final RULA score derived from the BBS process observations and assessments described above.

As shown in Table 1, 34 employees were working at the sales department. They worked 8 hours a day and gave a total of 2 hours break. Twenty-five (73.5\%) of the cases were male, and 9 (26.5\%) were female. The mean age was $39.7 \pm 5.7$ years. The youngest employee was 28 , the oldest was 51 years old. The mean period of employment was $93.7 \pm 70.8$ months. The employee with the shortest employment period had worked for 4 months, while the one with the 
Table 1. Demographic data of the patients included in the study

$\mathrm{n}: 34(\%)^{* *}$

\section{Gender}

Male

25 (73.5)

Female

$9(26.5)$

Age

Mean \pm SD

$34.6 \pm 5.0$

Chronic disease

Present

Not present

$31(91.2)$

\section{Educational background}

High school level and / or above

Marital status

Married or in a relationship

$26(76.5)$

Alone or apart

Smoking history

Active smoker

$22(64.7)$

Quit smoking

Never smoked

$6(17.6)$

Musculoskeletal system complaints (initial)*

Neck pain

$32(94.1)$

Neck stiffness

$15(44.1)$

Numbness and pins-and-needles sensation in arms

Back and lower back pain

$14(41.1)$

* When the employee had more than one complaint, all of the complaints were recorded

** The percentage of the column 
longest employment period had worked for 305 months.

Thirty-four (100\%) of the employees had an educational background of high school level and or above. Twenty-six (76.5\%) of the employees were either married or in a relationship. All employees had been inquired about their musculoskeletal system complaints by open-ended questions. The most common complaints were neck pain, which was expressed by $94.1 \%$ of the employees, and neck stiffness that was expressed by $44.1 \%$ of the employees.

As shown in Table 2, while the RULA score was $6.15 \pm 0.60$ prior the implementation, it was $5.12 \pm 0.80$ afterwards; and the minimum RULA score was 4 both before and after the implementation $(p<0.001)$. The presence of musculoskeletal complaints was $94.10 \%$ prior the implementation, while it was $61.7 \%$ afterwards $(p=0.03)$. The average number of days for which the employee had obtained a sickness absence report due to musculoskeletal system complaints (the number of sickness absence days) prior the implementation was 0 day (min 0 day-max 34 days) the average number of sickness absence days after the implementation was 0 day ( $\min 0$ day$\max 15$ days) $(p=0.30)$. The Sickness Absenteeism Incidence Rate (SAIR) prior the implementation was $235 \%$, while it was $176 \% \quad(p<0.001)$ afterwards. A statistically significant improvement has been seen between the mean RULA score and the SAIR obtained before and after the implementation. The presence of musculoskeletal system complaints before and after the implementation indicates a statistically significant improvement, while there is no statistically significant change regarding the number of sickness absence days.

The incidence rates for the number of days due to sickness before and after the BBS process, have been found $22.87 \%$, and $9.80 \%$ respectively $(p=<0.001)$.

\section{DISCUSSION}

Our research presents an implementation of the BBS process in order to prevent the musculoskeletal system diseases, and its results. There has been a statistically significant improvement in the RULA risk scores and the presence of musculoskeletal system complaints three months after the intervention implemented by the BBS team and WHSP. Although the BBS process focuses on the unsafe acts or behaviours of the employees, the main goal for implementing the BBS is not identifying the mistakes of the employees and then blaming them for their mistakes. Such usage of the process is unacceptable. The BBS process examines the problem as a whole, and the main purpose of the process is to identify the unsafe acts in order to improve the employees' health and safety (18). We believe that the main and initial goal of all occupational health implementations should be based on this idea.

The BBS process is mainly used in researches that aim to prevent or decrease work-related accidents. Komaki et al have presented some examples at the food manufacturing industry, and Choudhry at the construction sites $(19,7)$. Similar to our research, the core of their process was built on observation. Both researchers have reported that they have conducted long-term observations at the study site. As in our research, the observing employees have chosen the unsafe act to be prevented, and the data has been classified according to the frequency of the unsafe act, the number of employees it has affected, and its outcome. Komaki et al have reported that after the introduction of the program in two departments, the employees substantially improved their safety performance from $70 \%$ and $78 \%$ to $96 \%$ and $99 \%$, respectively (19). Choudhry has reported that the scores of safety performance at one project improved from $86 \%$ (at the end of 3rd week) to $92.9 \%$ during the 9th week (7). Al-Hemoud 
Table 2. The comparison of the results obtained before and after the implementation

\begin{tabular}{|c|c|c|c|}
\hline & $\begin{array}{l}\text { Before the } \\
\text { implementation ( } \mathrm{n}: 34)\end{array}$ & $\begin{array}{l}\text { After the implementation } \\
\qquad(\mathrm{n}: 34)\end{array}$ & $\mathbf{P}$ \\
\hline \multicolumn{4}{|l|}{ RULA score } \\
\hline \multirow[t]{2}{*}{ Median } & 6 & 5 & \\
\hline & & & $<0.001$ \\
\hline Minimum -maximum & $5-7$ & $4-7$ & \\
\hline \multicolumn{4}{|l|}{ The number of sickness absence days ${ }^{* * *}$} \\
\hline \multirow[t]{2}{*}{ Median } & 0 & 0 & \\
\hline & & & 0.67 \\
\hline Minimum -maximum & $0-34$ & $0-15$ & \\
\hline Sickness Absenteeism Incidence Rate ${ }^{* * * *}$ & $235 \%$ & $176 \%$ & $<0.001$ \\
\hline \multicolumn{4}{|l|}{$\begin{array}{l}\text { The presence of musculoskeletal } \\
\text { system complaints }\end{array}$} \\
\hline \multirow[t]{2}{*}{ Present } & $32(94.10)$ & $21(61.7)$ & \\
\hline & & & 0.03 \\
\hline Not present & $2(5.90)$ & 13 & \\
\hline
\end{tabular}

Paired sample t test, McNemar chi-square test, Wilcoxon test

The number of employee taken off due

$$
\text { to sickness }
$$

*** Sickness absenteeism incidence rate $=$ $\times 1000$

The number of employees

The number of days

to sickness

**** Incidence Rate Ratio $=$ $\times 1000$

The number of employees* 90 days 
et al have defined eight unsafe acts by using the BBS process that followed Komaki's behavioural safety model. Similar to our research, one of the unsafe acts that led to ergonomic risk factors was "incorrect sitting posture in front of the computer". They have reported that they have maintained a significant improvement at the safety index by using the BBS process (20). Many similar studies implement the BBS process for the prevention of work-related accidents (21-23).

There are also a few examples, similar to our research, regarding the BBS process' implementation at ergonomic interventions. Another good example for a research resembling ours is the one Mc Cann et al have carried out among office employees in order to prevent WRMSD. In a research aimed to decrease the frequency of Carpal Tunnel Syndrome (CTS) by implementing the BBS process, they have developed their own programme consisting of training, self-monitoring, feedback, goal-setting and reinforcement. While this research, similar to ours, has aimed to decrease the risk factors that lead to WRMSD by changing the unsafe act; it differs from ours by the usage of self-monitoring. Mc Cann et al have reported maintaining significant improvement in the CTS frequency. In our research, we have obtained a statistically significant improvement in the presence of musculoskeletal system complaints (14).

Spence, who has reviewed the various cognitive behaviour therapy (CBT) implementation examples and their results in his paper, has mentioned that these techniques are suitable especially for cases such as musculoskeletal system problems that occur due to long-term repetitive movements. CBT is also an important component of the rehabilitation process of the employees who proceed to a chronic pain condition (24). The musculoskeletal system complaints of 21 employees continued at the end of our research, but a rehabilitation programme was not planned for them.

It has been stated that the BBS process has short and long-term benefits. Lees et al have emphasised that the BBS process may increase the efficiency of the production. It has been reported that providing more comfortable and efficient conditions during production increases the employees' comfort, which correspondingly may lead to increase in production (12). Sulzer-Azaroff et al have stated that by preventing the potential accidents, work-related diseases or occupational diseases, it is possible to decrease health and safety-related expenses. In their research which they reviewed 33 articles regarding the implementation of the BBS process, they found out that 32 of them reported significant reductions in the direct and indirect costs related to the health and safety problems associated with the unsafe acts (22). In relation to these findings, we also have found significant improvement regarding the SAIR before and after the BBS implementation $(p<0.001)$. On the other hand, our study has not revealed any statistically significant change in the number of sickness absence days. This may be related to the fact that our re-evaluation was conducted only three months after the implementation, so that we may not have been sufficiently able to display the long term therapeutic effects of the intervention. The literature suggests conducting the re-evaluations after an observation period of 6 months to two years. It is suggested to conduct the long-term cost effectiveness re-evaluations after a one year or later (4).

The BBS process also has some unfavourable aspects. The major problem of the BBS and similar processes are regarding their sustainability. Zhang et al have emphasised that the effectiveness of even successful implementations decreases by time and that the risks increase back to the baseline levels. 
They have stated that this can only be prevented with processes that constantly take feedbacks. Therefore, they suggest the usage of SupervisoryBased Intervention Cycle in order to sustain the effects of the interventions (25). Geller has also emphasised that people may change their behaviours while the BBS process is carried out, but that it has to be reviewed according to the feedbacks. He has also indicated that the processes in which the participation is voluntary have outcomes that are more favourable (5). We believe that our success also relies on the fact that we have carried out the BBS process upon voluntary participation and that we have taken into consideration the employees' opinion at every step of the way.

Additionally, we have to criticise that the BBS programs only focus on the employees' unsafe acts and behaviours. It should be remembered that occupational diseases might also be prevented by implementing interventions on the working conditions $(26,27)$. The employer should perceive the process of eliminating the risks at the workplace as an opportunity to prevent outcomes that are more serious.

In conclusion, we have successfully carried out the BBS process that aimed to prevent" WRMSD in a small group. One of the favourable attributes of this process is its openness to improvement owing to the dynamic structure that can be supported from internal feedbacks. It has been observed that the employee's active or partial participation to the process at each step has increased the collaboration. As recommended, it is important to update the process according to the fee"dbacks that are received after the implementation. As our research has been carried out only with a small group of employees, the feasibility and especially the longterm results of the process should be evaluated with bigger groups. This process may be considered as a promising approach for the prevention of WRMSD. 


\section{REFERENCES}

1. International Labour Office (ILO). The prevention of occupational disease. 2013, Geneva. Available from http://www.ilo.org/wcmsp5/groups/public/--ed_protect/---protrav/---safework/documents/ publication/wcms_208226.pdf (Accessed date: 01.02.2016).

2. World Health Organization (WHO). The global burden of disease 2004 update. 2004, Geneva. Available from http://www.who.int/healthinfo/ statistics/GlobalDALYmethods_2000_2011.pdf. (Accessed date: 01.02.2016).

3. Tanır F, Guzel R, Issever H, Polat U. Musculoskeletal disorders in an automotive manufacturing plant and the outcomes of ergonomics and exercise training in workers who used sick leave. Turkish Journal of Phys Med Rehab, 2013; 59(3):214-21.

4. Norman R, Wells R. Ergonomic interventions for reducing musculoskeletal disorders: an overview, related issues and future directions. Department of Kinesiology Faculty of Applied Health Sciences University Of Waterloo, 1998.

5. Geller ES. Behavior-based safety and occupational risk management. Behav Modif, 2005; 29(3): 53961.

6. Manuele AF. On the practise of safety. 4th ed. USA: John Wiley and Sons, 2013.

7. Choudhry RM. Behavior-based safety on construction sites: a case study. Accid Anal Prev, 2014; 70:14-23

8. Dickerson JM, Koch BL, Adams JM, Goodfriend MA, Donnelly LF. Safety coaches in radiology: decreasing human error and minimizing patient harm. Pediatr Radiol, 2010; 40(9): 1545-51.

9. Hermann JA, Ibarra GV, Hopkins BL. A safety program that integrated behavior based safety and traditional safety methods and its effects on injury rates of manufacturing workers. J Organ Behav Manage, 2010; 30(1): 6-25.

10. Hickman JS, Geller ES. A safety self-management intervention for mining operations. J Safety Res, 2003; 34 (3):299-308.
11. Carter N. Behavior analysis and the primary prevention of occupational injuries. Scan J Behav Therapy, 1992; 21(2): 89-103.

12. Less $H$, Faulkner $B$. Linking production to safety: boosting productive performance through behavior- based safety. G Ital Med Lav Ergon, 2010; 32(Suppl 1): 24a-7.

13. Krause TR, Seymour KJ, Sloat KCM. Long-term evaluation of a behavior-based method for improving safety performance: a meta-analysis of 73 interrupted time-series replications. Safety Science, 1999; 32 (1): 1-18.

14. McCann KB, Azaroff BS. Cumulative trauma disorders: behavioral injury prevention at work. The J App Behav Sci, 1996; 32(3): 277-91.

15. Atamney M, Corlett EN. RULA: a survey method for the investigation of work-related upper limb disorders. Appl Ergon, 1993; 24(2):91-9.

16. Ozturk N, Esin MN. Ergonomik riskleri belirleme: calıșanın üst ekstremitelerini değerlendirme formunun tanıtımı. Mesleki Sağlık ve Güvenlik Dergisi, 2007; 30(8):31-7.

17. Pala K. iș yeri hekimleri için iș sağlığı epidemiyolojisine giriș. Mesleki Sağlık ve Güvenlik Dergisi, 2001; 8(2):14-8.

18. Frederick J, Lessin N. Blame the worker. The rise of behavioral-based safety programs. The Multinational Monitor, 2000; 21(11).

19. Komaki J, Barwick KD, Scott LR. A behavioral approach to occupational safety: pinpointing and reinforcing safe performance in a food manufacturing plant. J Appl Psychol, 1978; 63(4): 434-45.

20. Al-Hemoud AM. Al-Asfoor MM. A behavior based safety approach at a Kuwait research institution. J Safety Res, 2006; 37(2): 201-6.

21. Blackmon RB, Gramopadhye AK. Improving construction safety by providing positive feedback on backup alarms. J Constr Eng Manag, 1995; 121 (2):166-71. 
22. Sulzer-Azaroff B, Austin J. Does BBS work? Behavior-based safety and injury reductions: a survey of the evidence. Prof Saf, 2000; 45(7):1924.

23. Saari J, Nasanen M. The effect of positive feedback on industrial housekeeping and accidents: A longterm study at a shipyard. Int J Ind Ergon, 1989; 4(3): 201-11.

24. Spence SH. Cognitive-behavior therapy in the management of upper extremity cumulative trauma disorder. J Occup Rehabil, 1998; 8(1):2745.
25. Zhang M, Fang D. Continuous Behavior-Based Safety strategy for persistent safety improvement in construction industry. Automation in Construction, 2013; 34: 101-7.

26. Özcan E, Kesiktas N. Mesleki kas iskelet hastalıklarından korunma ve ergonomi. İs Sağlığ ve Güvenliği Dergisi, 2007; 34: 6-9.

27. Ulin SS, Keyserlink WIM. Case studies of ergonomic interventions in automotive parts distrubition operations. J Occup Rehabil, 2004; 14(4): 307-26. 